\author{
SEBASTIAN WojTKIEWICZ \\ Uniwersytet Szczeciński, Polska \\ University of Szczecin, Poland \\ TADEUSz BochEŃSKI \\ Uniwersytet Szczeciński, Polska \\ University of Szczecin, Poland
}

\title{
Rozwój przemysłu taboru kolejowego w Polsce na przełomie XX i XXI wieku
}

\section{Development of the Railway Rolling Stock Industry in Poland at the Turn of the 20th and 21st Century}

\begin{abstract}
Streszczenie: Celem pracy było zbadanie rozwoju zakładów produkcji i modernizacji taboru kolejowego w Polsce. Przeanalizowano przekształcenia przedsiębiorstw zajmujących się produkcją i remontami taboru kolejowego w Polsce na przełomie XX i XXI wieku oraz wielkość produkcji taboru kolejowego w latach 2001-2016. Omówiono także eksport polskiego taboru za granicę. Produkcją, modernizacją i naprawą taboru kolejowego zajmowało się w Polsce kilkadziesiąt zakładów, w tym zakłady należące do zagranicznych koncernów, tj. Stadler, Bombardier i Greenbier. Największymi przedsiębiorstwami zajmującymi się produkcją i modernizacją taboru z rodzimym kapitałem w Polsce stały się na początku XXI wieku Pesa i Newag, nieco mniejsze znaczenie miał HCP FPS. Po kryzysie na przełomie XX i XXI wieku, wynikającym z sytuacji w PKP oraz procesów transformacji gospodarczej kraju, przemysł taboru kolejowego w Polsce zaczął się ponownie rozwijać. Duży wpływ na to miało wejście Polski do UE oraz otwarcie rynku kolejowego. Niemniej jednak upadły duże zakłady, takie jak PaFaWag i Fablok. Znacząco zmniejszyła się liczba zakładów naprawczych taboru - dawnych ZNTK, z których część upadła, a część została zrestrukturyzowana i w kilku przypadkach rozszerzyła zakres działalności.
\end{abstract}

\begin{abstract}
The aim of the study was to examine the development of production plants and modernisation of railway rolling stock in Poland. The transformations of enterprises manufacturing and repairing rolling stock in Poland at the turn of the 20th and 21st century and the volume of rolling stock production in the years 2001-2016 were analysed. Export of Polish rolling stock abroad was also discussed. Production, modernisation and repair of railway rolling stock in Poland was handled by several dozen plants, including those belonging to foreign concerns such as Stadler, Bombardier and Greenbier. The largest enterprises dealing in the production and modernisation of rolling stock with domestic capital in Poland at the beginning of the 21st century were Pesa and Newag, the HCP FPS was slightly less important. After the crisis at the turn of the 20th and 21st century resulting from the situation in PKP and the processes of economic transformation of the country, the rolling stock industry in Poland began to develop again. Poland's accession to the EU and the opening of the rail market have had a major impact. However, large plants such as PaFaWag and Fablok have fallen. The number of rolling stock repair plants (old ZNTK) decreased significantly, some of them went bankrupt and some of them were restructured and in a few cases expanded their scope of activity.
\end{abstract}

Słowa kluczowe: naprawa taboru; produkcja taboru; tabor kolejowy

Keywords: railway rolling stock; rolling stock production; rolling stock repair 
Otrzymano: 30 grudnia 2017

Received: 30 December 2017

Zaakceptowano: 6 lipca 2018

Accepted: 6 July 2018

\section{Sugerowana cytacja / Suggested citation:}

Wojtkiewicz, S., Bocheński, T. (2018). Rozwój przemysłu taboru kolejowego w Polsce na przełomie XX i XXI wieku. Prace Komisji Geografii Przemysłu Polskiego Towarzystwa Geograficznego, 32(3), 157-173. https:// doi.org/10.24917/20801653.323.10

\section{WSTĘP}

Zmiany gospodarcze oraz problemy PKP na przełomie XX i XXI wieku spowodowały brak zamówień na nowy tabor w kraju. Część zakładów została zrestrukturyzowana, a inne upadły. Ożywienie sektora produkcji taboru kolejowego nastąpiło po wejściu Polski do Unii Europejskiej. Zrestrukturyzowano PKP, a rynek kolejowy w 2002 roku został zliberalizowany i na torach pojawili się nowi przewoźnicy. Dodatkowo samorządy wojewódzkie stały się organizatorami kolejowych przewozów regionalnych i dzięki funduszom z UE i EFTA zaczęły inwestować w tabor kolejowy - modernizację starego i zakup nowego. Również PKP Intercity, obsługująca przewozy dalekobieżne, rozpoczęła proces odnowy taboru.

Produkcją, modernizacją i naprawą taboru kolejowego zajmowało się w Polsce kilkadziesiąt zakładów. Były wśród nich zarówno firmy polskie, jak i zakłady należące do międzynarodowych koncernów, tj.: Bombardier, Stadler, Greenbier Europe. Ponadto wiele innych firm produkowało różnego rodzaju podzespoły (Bocheński, 2016).

Celem pracy było zbadanie rozwoju zakładów produkcji i modernizacji taboru kolejowego w Polsce. Przeanalizowano przekształcenia przedsiębiorstw zajmujących się produkcją i remontami taboru kolejowego w Polsce na przełomie XX i XXI wieku oraz wielkość produkcji taboru kolejowego w latach 2001-2016. Wyodrębniono zakłady i produkcję krajowych i zagranicznych przedsiębiorstw na terenie Polski. Omówiono także eksport polskiego taboru za granicę.

We współczesnej literaturze naukowej niniejszy temat nie był szerzej analizowany przez geografów i ekonomistów. T. Bocheński (2016) pisał o przemyśle na rzecz kolei, obejmującym zarówno tabor, jak i infrastrukturę, w kontekście powiązań kolei zprzemysłem.Znaleźćmożnatakżeartykułypoświęconeaspektom technicznymprodukcji lub modernizacji danego typu taboru, np. R. Lercha (2012) i A. Turowskiego (2012).

Wykorzystane $\mathrm{w}$ niniejszym opracowaniu materiały źródłowe obejmowały przede wszystkim informacje publikowane przez przedsiębiorstwa zajmujące się produkcją i modernizacją taboru, urzędy marszałkowskie, Railway Busines Forum oraz artykuły w prasie, w tym w czasopismach branżowych, jak np. „Rynek Kolejowy”. Ważnym źródłem informacji, m.in. o użytkowaniu produkowanego w Polsce taboru, były rozmowy z pracownikami zachodniopomorskiego oddziału Przewozów Regionalnych w Szczecinie.

\section{PRZEKSZTAECENIA PRZEDSIĘBIORSTW PRODUKCJI I NAPRAWY TABORU KOLEJOWEGO W POLSCE}

Do lat dziewięćdziesiątych XX wieku największym producentem taboru kolejowego w Polsce i jednym z największych w Europie był PaFaWag we Wrocławiu. Zakład ten 
produkował elektrowozy, wagony pasażerskie i EZT. W 1997 roku został wykupiony przez grupę Adtranz utworzoną przez ABB i Daimler Benz. W 2001 roku grupa ta została przejęta przez kanadyjski koncern Bombardier Transportation. Od tego czasu zakład we Wrocławiu specjalizuje się w budowie pudeł, ram i wózków elektrowozów na potrzeby koncernu, głównie dla kolei zagranicznych (Sobolewski, 2001). Drugim co do wielkości producentem były zakłady H. Cegielskiego w Poznaniu. Zakłady, przemianowane w PRL-u na Fabrykę Lokomotyw i Wagonów, w 1997 roku przekształcono w H. Cegielski - Fabryka Pojazdów Szynowych Sp. z o.o. (HCP FPS). W 2010 roku zakład został przejęty przez Agencję Rozwoju Przemysłu S.A. Firma specjalizowała się w produkcji wagonów pasażerskich (H. Cegielski..., 2017).

Głównym producentem wagonów towarowych w Polsce były do początku lat dziewięćdziesiątych XX w. Zaodrzańskie Zakłady Przemysłu Maszynowego ZASTAL w Zielonej Górze. W 1992 roku majątek zakładów przejął ZASTAL S.A., a następnie utworzony został park przemysłowy. Powstała grupa kapitałowa, w której funkcjonowała m.in. Zastal Wagony Sp. z o.o. Produkcji wagonów zaprzestano w pierwszej dekadzie XXI wieku i wytwarzano jedynie konstrukcje stalowe (ZASTAL S.A., 2017). Od 2014 roku ZASTAL zajmuje się głównie produkcją kontenerów, ale w planach ma powrót do produkcji wagonów (Zastal robi..., 2014). Innym producentem wagonów towarowych w Polsce była Fabryka Wagonów Świdnica - sprywatyzowana w 1992 roku, a w 1998 roku wykupiona przez amerykański koncern The Greenbrier Companies. Weszła w skład Greenbrier Europe i działała pod szyldem Wagony Świdnica S.A., która w 2016 roku została przekształcona w sp. z o.o. (Railway Busines Forum, 2017).

Ważnym producentem była także Pierwsza Fabryka Lokomotyw w Polsce FABLOK S.A. w Chrzanowie, specjalizująca się w produkcji i modernizacji lokomotyw spalinowych, w tym najdłużej produkowanej w Polsce serii SM42 - w latach 1963-1992 (Irteński, 2013). Następnie spółka ta wytwarzała żurawie kołowe. W 2013 roku ogłoszono upadłość zakładu (Balicka, 2013; Pierwsza Fabryka..., 2017). W 2015 roku część dawnej fabryki wydzierżawił Energo Mechanik Sp. z o.o., który jest częścią grupy Martech. Firma ta produkuje m.in. lokomotywy przemysłowe dla górnictwa (Balicka, 2015).

W Raciborzu funkcjonowały Kolejowe Zakłady Maszyn, do 1991 roku w strukturach PKP jako KZMiSD „Racibórz”, następnie przemianowane na KOLZAM S.A., a potem REMKOL Sp. z o.o. W 2007 roku zakład został wykupiony przez węgierską spółkę Mavex-Rekord KFT. i stał się jej oddziałem. Firma produkuje i modernizuje kolejowe pojazdy specjalne oraz podzespoły do taboru kolejowego (Mavex-Rekord Kft., 2017).

W 1993 roku powstało przedsiębiorstwo Zakłady Produkcyjno-Naprawcze Taboru Maszyn i Urządzeń (ZPNTMiU) „Tabor” M. Dybowski, z którego w 2013 roku wydzieliła się Tabor Dębica Sp. z o.o. (Tabor Dębica Sp. z o.o., 2017).

W Siedlcach w 2007 roku otworzono zakład montażowy szwajcarskiego koncernu Stadler. Jego powstanie związane było z kontraktem tego koncernu na dostawę taboru dla polskich przewoźników (Stadler Polska Sp. z o.o., 2017).

Ważną rolę odgrywały Zakłady Naprawy Taboru Kolejowego (ZNTK) specjalizujące się głównie w naprawie i modernizacji taboru. W 1991 roku ZNTK zostały wydzielone ze struktury PKP jako odrębne przedsiębiorstwa. W wyniku restrukturyzacji część z nich rozszerzyła zakres działalności o produkcję nowych pojazdów. Na początku lat dziewięćdziesiątych XX wieku działały 22 ZNTK, a w 2000 roku było ich 14, w tym dwa zakłady naprawy lokomotyw. Pod szyldem ZNTK w 2017 roku pozostawało sześć przedsiębiorstw. 
Na bazie dawnych ZNTK powstały m.in. dwa aktualnie największe na polskim rynku przedsiębiorstwa produkcji taboru. Proces restrukturyzacji obu zakładów rozpoczął się w 2001 roku. Sprywatyzowano wówczas ZNTK Bydgoszcz, która zmieniła nazwę na Pojazdy Szynowe Pesa Bydgoszcz Spółka Akcyjna Holding. Od tego momentu spółka ta prowadziła produkcję spalinowych zespołów trakcyjnych (SZT). Pesa stała się też dużym dostawcą tramwajów (Pesa, 2017). Natomiast ZNTK Nowy Sącz sprywatyzowano w 2003 roku, a w 2005 roku zmienił nazwę na Newag S.A. Od 2001 roku w Nowym Sączu modernizowano lokomotywy i EZT, od 2003 roku produkowano nowe EZT, a od 2010 roku także SZT (Newag S.A., 2017).

ZNTK Mińsk Mazowiecki S.A. powstał w wyniku restrukturyzacji w 1996 roku. W latach 2008-2009 większościowy pakiet akcji wykupiła Pesa Bydgoszcz S.A. i spółka weszła do grupy kapitałowej Pesa (Pesa dokupiła..., 2017; Pesa Bydgoszcz, 2017). Następnie zakład rozszerzył działalność o produkcję SZT (ZNTK Mińsk..., 2017).

ZNTK Opole w 2002 roku został sprywatyzowany i przekształcony w Tabor Szynowy Opole S.A. W 2014 roku spółka ta została postawiona w stan upadłości, a w 2015 roku jej majątek przejęła Wagon Opole Sp. z o.o. Firma ta zajmuje się modernizacją wszelkiego typu pojazdów kolejowych oraz produkuje części i podzespoły (Wagon Opole Sp. z o.o., 2017).

Dwa ZNTK przekształcono w latach dziewięćdziesiątych XX wieku na Zakłady Naprawcze Lokomotyw Spalinowych (ZNLS) w Pile i Elektrycznych (ZNLE) w Gliwicach. Pierwsze z nich upadły w 2003 roku. Natomiast ZNLE Gliwice sprywatyzowano w 2001 roku, a w 2008 roku weszły do Grupy Newag. W 2013 roku zmieniono nazwę na Newag Gliwice, zaś w 2016 roku podjęto decyzję o przeniesieniu produkcji lokomotyw do Nowego Sącza (Newag Gliwice, 2017).

Cztery kolejne ZNTK wyspecjalizowały się w produkcji i modernizacji wagonów towarowych różnego typu. ZNTK Gniewczyna rozpoczął ich produkcję w 1996 roku, następnie w 1999 roku zmieniono nazwę zakładu na Fabryka Wagonów Gniewczyna S.A. (FWG), a w 2001 roku zakład sprywatyzowano (Fabryka Wagonów Gniewczyna, 2017). W 2014 roku spółka utraciła płynność finansową i w 2015 roku została postawiona w stan upadłości likwidacyjnej. W 2017 roku trwały rozmowy nad wznowieniem produkcji - przejęciem zakładu zainteresowana była PKP Cargo (Narada w..., 2017). W 1995 roku rozpoczął się proces prywatyzacji ZNTK Ostrów Wielkopolski, który następnie od 1999 roku funkcjonował pod nazwą Fabryka Wagon, a od 2005 roku jako Europejskie Konsorcjum Kolejowe Wagon (EKK Wagon, 2017). ZNTK Ostróda, należąca wcześniej do PKP i CPN DEC (Dyrekcja Eksploatacji Cystern), w 2001 roku została sprywatyzowana i razem z DEC przejęta przez amerykański koncern GATX. Obecnie działa jako Wagon Service Ostróda Sp. z o.o. i należy do GATX Rail Poland Sp. z o.o. Zakład ten posiada placówkę w Płocku i specjalizuje się w produkcji i naprawach wagonów cystern (WSO Ostróda, 2017). Kolejnym zakładem w tym segmencie rynku był ZNTK Oława, zrestrukturyzowany w 1996 roku i przekształcony w sp. z o.o. W 2011 roku spółka ta weszła do grupy Greenbrier Europe (ZNTK Oława, 2017).

ZNTK Stargard Szczeciński w 2000 roku został przekształcony w Fabrykę Pojazdów Szynowych. Po jej upadku w latach 2003-2006 na terenie zakładu działalność prowadziło przedsiębiorstwo MTR, które następnie zmieniło nazwę na ZPS Sp. z.o.o. Zakład produkował lokomotywy manewrowe, drezyny i pojazdy dla kolejowych służb elektroenergetycznych (ZPS, 2017). 
Cztery przedsiębiorstwa działające w 2017 roku i wywodzące się z ZNTK nie zdecydowały się na rozpoczęcie produkcji taboru i w dalszym ciągu skupiały się na jego naprawach i modernizacji. Były to: ZNTK Oleśnica S.A., ZNTK Paterek S.A. koło Nakła nad Notecią i ZNTKiM Sp. z o.o. w Gdańsku (Zakłady Naprawcze Taboru Kolejowego i Miejskiego). Natomiast ZNTK Radom Sp. z o.o. prowadził jedynie produkcję części i podzespołów (ZNTK Radom, 2017).

Specyficznym zakładem był P.U.P. Interlok Sp. z o.o., wyodrębniony w 1989 roku z ZNTK Piła, który specjalizował się przede wszystkim w naprawie i kompleksowej odbudowie parowozów (Interlok Sp. z o.o., 2017). Był to jeden z trzech ostatnich zakładów w Europie wykonujący parowozy.

Całkowitej likwidacji w latach dziewięćdziesiątych XX wieku uległy ZNTK: Wrocław, Biłgoraj, Pruszków, Słupsk i Lubań, zaś po 2000 roku także: ZNLS Piła w 2003 roku, ZNTK Łapy w 2009 roku i ZNTK Poznań. W 2005 roku ZNTK Poznań został przejęty przez Sigma S.A., a w 2009 roku zaprzestał działalności. Tereny zakładów w 2013 roku wystawiono na sprzedaż, a na ich miejscu ma powstać nowa, mieszkaniowobiznesowa dzielnica miasta (Cieśla, 2016). ZNTK Poznań, oprócz produkcji całych pojazdów, m.in. szynobusów, był ważnym producentem wózków wagonowych, w tym wózków z systemem samoczynnej zmiany rozstawu kół SUW2000 oraz do pojazdów osiągających prędkość 200 km/godz. (Piech, 2007).

W 2017 roku w Polsce funkcjonowało 17 zakładów zajmujących się budową lub modernizacją taboru kolejowego (tab. 1). Ponadto działało około 40 zakładów specjalizujących się w remontach i utrzymaniu taboru kolejowego, z których 15 należało do PKP Cargo Tabor Sp. z o.o. (Bocheński, 2016). Część przewoźników kolejowych posiadało w swoich strukturach zakłady taboru z zapleczem technicznym umożliwiającym wykonywanie jego przeglądów i remontów na własne potrzeby. W niektórych zakładach dokonywano także modernizacji - np. w Zakładzie Taboru Kolejowego Rail Polska Sp. z o.o. we Włosienicy (ZTK Rail Polska) przeprowadzono modernizację lokomotywy M62 (Rail Polska Sp. z o.o., 2017), a w Zakładzie Napraw Taboru Przewozów Regionalnych w Kruszewcu (Idzikowice) zmodernizowano EZT serii EN72 (Madrjas, 2016, 21 kwietnia).

W tab. 1 przedstawiono główne przedsiębiorstwa zajmujące się produkcją nowego i modernizacją starego taboru kolejowego w Polsce, zaś na ryc. 1 - ich rozmieszczenie.

Tab. 1. Przedsiębiorstwa zajmujące się produkcją i modernizacją taboru kolejowego w Polsce

\begin{tabular}{|c|c|c|}
\hline $\begin{array}{l}\text { Nazwa przedsiębiorstwa } \\
\text { i lokalizacja }\end{array}$ & \multicolumn{2}{|r|}{ Specjalizacja - rodzaj produkowanego i modernizowanego taboru } \\
\hline A & \multicolumn{2}{|r|}{ B } \\
\hline \multirow[t]{2}{*}{$\begin{array}{l}\text { Pojazdy Szynowe } \\
\text { Pesa Bydgoszcz S.A. }\end{array}$} & $\mathrm{P}$ & $\begin{array}{l}\text { EZT: Elf, Dart, Acatus Plus } \\
\text { SZT: Link, 730M, ATR220 i inne } \\
\text { WP: piętrowe systemu Push-Pull } \\
\text { LS: Gama 111Db } \\
\text { LE wielosystemowa: Gama 111MS } \\
\text { LE-S: Gama Marathon 111Ed } \\
\text { pojazd inspekcyjny SZT - 611M }\end{array}$ \\
\hline & $\mathrm{M}$ & $\begin{array}{l}\text { LE: 303E (EU07) } \\
\text { LS: Ls800E (SM42), 301D (SU45/46), M62 (ST44) } \\
\text { WP różnych typówW } \\
\text { EZT: EN57 }\end{array}$ \\
\hline
\end{tabular}




\begin{tabular}{|c|c|c|}
\hline \multirow[t]{2}{*}{$\begin{array}{l}\text { Newag S.A. } \\
\text { (zakłady w Nowym Sączu } \\
\text { i Gliwicach) }\end{array}$} & $\mathrm{P}$ & $\begin{array}{l}\text { EZT: Impuls } \\
\text { SZT: 220M, 221M, 222M } \\
\text { LE: E6ACT Dragon, E4MSU Griffin }\end{array}$ \\
\hline & M & $\begin{array}{l}\text { EZT: EN57 i EN71 } \\
\text { LS: SM42 i SM48 } \\
\text { WP różnych typów }\end{array}$ \\
\hline \multirow{2}{*}{$\begin{array}{l}\text { H. Cegielski Fabryka Pojazdów } \\
\text { Szynowych } \\
\text { Sp. z o.o. w Poznaniu }\end{array}$} & $\mathrm{P}$ & WP różnych typów \\
\hline & M & $\begin{array}{l}\text { LE: EU07, EZT: EN57 } \\
\text { WP różnych typów }\end{array}$ \\
\hline \multirow[t]{2}{*}{ ZNTK Mińsk Mazowiecki S.A. } & $\mathrm{P}$ & SZT: SA135 \\
\hline & M & EZT: EN57, EN71, ED72 \\
\hline \multirow{2}{*}{$\begin{array}{l}\text { TABOR M. Dybowski Sp.j. } \\
\text { w Dębicy }\end{array}$} & $\mathrm{P}$ & WT: platformy, węglarki, cysterny \\
\hline & M & LS \\
\hline $\begin{array}{l}\text { Fabryka Wagonów Gniewczyna } \\
\text { S.A }\end{array}$ & \multirow{3}{*}{ PM } & \multirow[t]{3}{*}{$\begin{array}{l}\text { WT różnych typów (w tym: węglarki, platformy, } \\
\text { samowyładowcze, kryte) }\end{array}$} \\
\hline $\begin{array}{l}\text { EKK Wagon Sp. z o.o. - Ostrów } \\
\text { Wielkopolski }\end{array}$ & & \\
\hline ZNTK Oława Sp. z o.o. & & \\
\hline WSO Ostróda Sp. z o.o. & PM & WT cysterny \\
\hline ZPS Sp. z o.o. - Stargard & \multirow[b]{2}{*}{ PM } & \multirow[t]{2}{*}{ pojazdy specjalne } \\
\hline $\begin{array}{l}\text { Mavex-Rekord Sp. z o.o.- } \\
\text { Racibórz }\end{array}$ & & \\
\hline $\begin{array}{l}\text { Wagony Świdnica S.A. } \\
\text { (Greenbier Europe) }\end{array}$ & $\mathrm{P}$ & $\begin{array}{l}\text { WT różnych typów (w tym: węglarki, platformy, } \\
\text { samowyładowcze, cysterny, do cementu, kryte z przesuwnymi } \\
\text { ścianami) }\end{array}$ \\
\hline $\begin{array}{l}\text { Stadler Polska } \\
\text { Sp. z o.o. w Siedlcach }\end{array}$ & $\mathrm{P}$ & EZT: Flirt \\
\hline $\begin{array}{l}\text { Bombardier Transportation } \\
\text { Polska Sp. z o.o. Wrocław }\end{array}$ & $\mathrm{P}$ & $\begin{array}{l}\text { LE: nadwozia i ramy wózków Traxx } \\
\text { EZT: nadwozia ICx }\end{array}$ \\
\hline ZNTK Oleśnica S.A. & $\mathrm{M}$ & EZT, LE, LS \\
\hline ZNTK Paterek S.A. & M & WT \\
\hline Wagon Opole Sp. z o.o. & M & EZT, WP, WT, pojazdy specjalne \\
\hline
\end{tabular}

Objaśnienia użytych skrótów:

P - produkcja, M - modernizacja, EZT - elektryczne zespoły trakcyjne, SZT - spalinowe zespoły trakcyjne, LS - lokomotywy spalinowe, LE - lokomotywy elektryczne, LE-S - lokomotywy elektryczno-spalinowe, WT wagony towarowe, WP - wagony pasażerskie

Źródło: opracowanie własne na podstawie informacji publikowanych przez poszczególne przedsiębiorstwa

Ważna część działalności przemysłu kolejowego związana była z produkcją części zamiennych i podzespołów zarówno do nowych, jak i do modernizowanych pojazdów kolejowych. W Polsce działało ponadto kilkadziesiąt zakładów produkujących różnego rodzaju podzespoły do taboru kolejowego. W Polskiej Izbie Producentów Urządzeń i Usług na Rzecz Kolei z siedzibą w Bydgoszczy zrzeszonych było 50 przedsiębiorstw prowadzących działalność w tym zakresie (Bocheński, 2016). Wytwarzano w nich m.in.: odbieraki prądu, falowniki i przetwornice, aparaturę trakcyjną (tab. 2). Ponadto w wielu zakładach w Polsce wytwarzano wózki wagonowe. Pomimo to znaczna część podzespołów do produkowanych i modernizowanych w Polsce pojazdów pochodziła $\mathrm{z}$ importu. 
Ryc. 1. Zakłady produkcji i modernizacji oraz napraw taboru kolejowego w Polsce

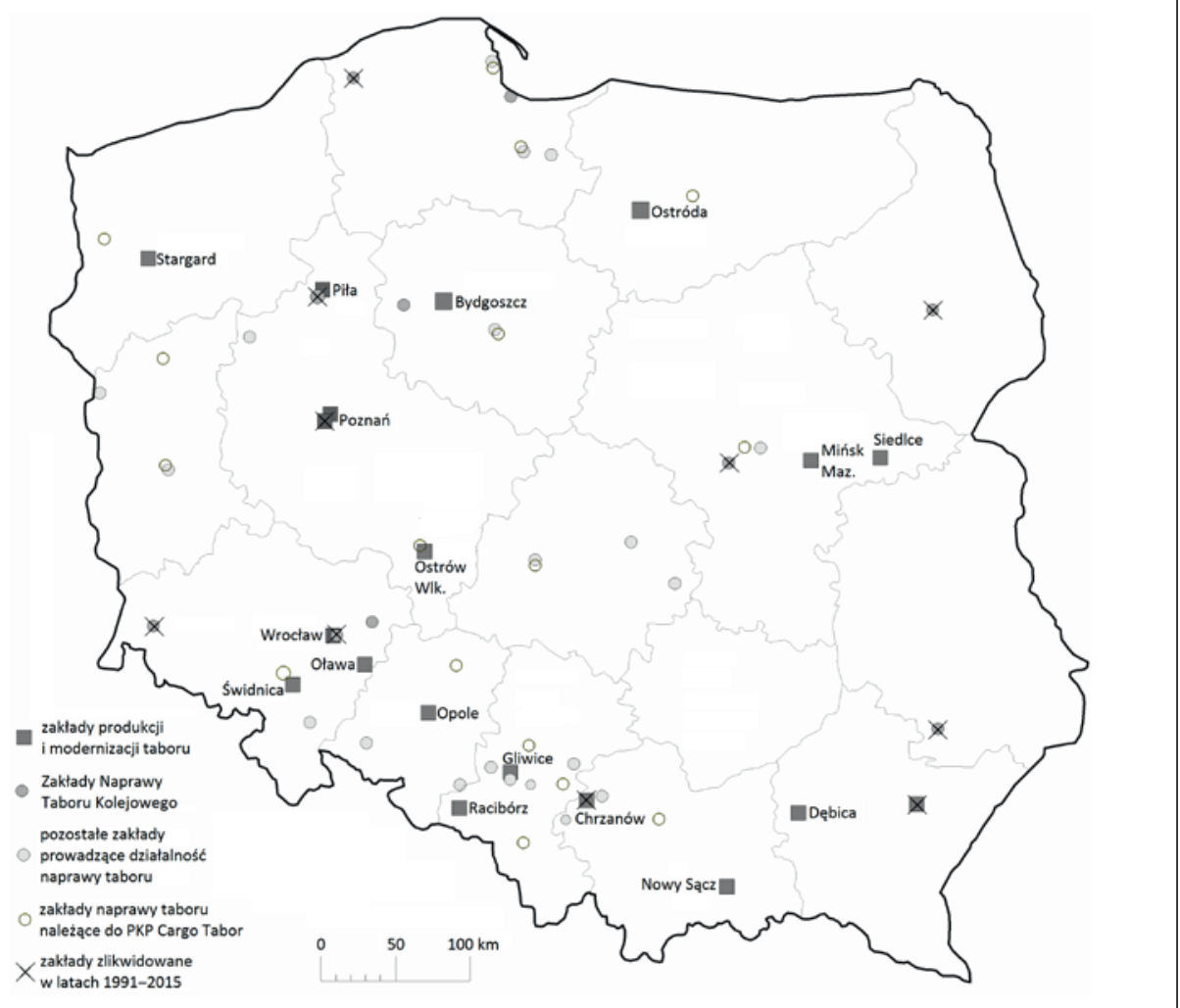

Źródło: opracowanie własne na podstawie Bocheński (2016); informacje publikowane przez PKP Cargo, Rail Polska i przedsiębiorstwa remontu taboru

Tab. 2. Wybrani producenci podzespołów taboru kolejowego w Polsce

\begin{tabular}{|c|c|c|}
\hline Nazwa zakładu & Element & Miejscowość \\
\hline EC Engineering Sp. z o.o. & odbierak prądu & Kraków \\
\hline Bombardier Transportation Polska Sp. z o.o. & $\begin{array}{l}\text { aparatura trakcyjna } \\
\text { do elektrowozów }\end{array}$ & Łódź \\
\hline Instytut Pojazdów Szynowych TABOR & sterowanie & Poznań \\
\hline MEDCOM Sp. z o.o. & $\begin{array}{l}\text { falowniki trakcyjne, } \\
\text { elektronika }\end{array}$ & Warszawa \\
\hline Zakład Elektroniki Przemysłowej ENIKA Sp. z o.o. & przetwornice & Łódź \\
\hline Zakład Maszyn Elektrycznych EMIT S.A. & silniki & Żychlin \\
\hline DARPOL Sp. z. o.o. & $\begin{array}{l}\text { szeroki asortyment części } \\
\text { i akcesoriów do różnego } \\
\text { rodzaju taboru }\end{array}$ & Bydgoszcz \\
\hline Stemmann-Polska Sp. z o.o. & odbierak prądu & Kąty Wrocławskie \\
\hline ZNTK Radom Sp. z. o.o. & elementy metalowe & Radom \\
\hline Bombardier Transportation Polska & aparatura trakcyjna & Łódź \\
\hline Axtone S.A. & $\begin{array}{l}\text { zderzaki, amortyzatory, } \\
\text { urządzenia cięgłowe }\end{array}$ & Kańczuga \\
\hline
\end{tabular}

Źródło: opracowanie własne na podstawie informacji publikowanych przez poszczególne przedsiębiorstwa 


\section{ProduKCJA NOWEgo TABORU W PolsCE W LATACH 2001-2016}

W latach dziewięćdziesiątych XX wieku z powodu trudności PKP rynek produkcji taboru kolejowego uległ załamaniu. Dopiero pojawienie się możliwości dofinansowania inwestycji taborowych z funduszy UE i EFTA oraz przejęcie organizacji przewozów aglomeracyjnych i regionalnych przez samorządy spowodowały pojawienie się zamówień na nowy tabor. W pierwszej kolejności dokonywano zakupów spalinowych zespołów trakcyjnych (SZT), nazywanych też autobusami szynowymi, a wcześniej wagonami motorowymi. Były one przeznaczane do obsługi linii niezelektryfikowanych, a ich zastosowanie umożliwiało zmniejszenie kosztów wykonywania przewozów. PKP posiadało niewiele tego typu taboru, a jego produkcję w Polsce rozpoczęto dopiero w latach osiemdziesiątych XX wieku. Jako pierwszy w Polsce w 1988 roku produkcję autobusów szynowych podjął Kolzam w Raciborzu. W zakładzie tym powstało kilka krótkich serii, w tym SN81 i SA104/SA122. Następnie produkcją SZT zajął się ZNTK Poznań, w którym powstały serie SA101/121 i SA102/SA111. Łącznie w latach dziewięćdziesiątych XX wieku powstało 13 pojazdów. Wszystkie pochodzące z tamtego czasu pojazdy do końca 2016 roku zostały wycofane z eksploatacji ze względu na niedostosowanie do współczesnych wymagań (Fiszer, 2016). Obie firmy kontynuowały produkcję na początku XXI wieku. Ogółem ZNTK Poznań wypuścił 17 pojazdów, a Kolzam 13, które kupiły samorządy województw (BIP urzędów marszałkowskich). Od 2005 roku produkcję SZT prowadziła Pesa Bydgoszcz, która do 2016 roku wyprodukowała łącznie 341 SZT różnych typów, czyli 87,1\% krajowej produkcji. Wielkość produkcji w niektórych latach sięgała ponad 40 pojazdów. Również Newag od 2010 roku zajął się produkcją SZT, ale do 2016 roku - z powodu późniejszego wejścia w ten segment rynku - wyprodukował tylko 19 pojazdów (ryc. 3). Newag produkował składy dwu- i trójczłonowe, zaś Pesa dodatkowo jednoczłonowe (Pesa Bydgoszcz, 2017; Newag S.A., 2017).

Rozwój tego rodzaju pojazdów uwarunkowany był dużym zapotrzebowaniem na rynku krajowym. Produkowane przez polskie przedsiębiorstwa SZT w 56,2\% powstały na potrzeby rynku krajowego, a w $43,8 \%$ na eksport (ryc. 2). Pesa miała w ofercie m.in. składy na tor $1520 \mathrm{~mm}$. W 2016 roku otrzymała dopuszczenie na rynek niemiecki jako jedna z pierwszych na świecie firm produkujących poza Niemcami (Madrjas, 2016, 03 czerwca). Pesa wyeksportowała łącznie 47 SZT w wersji szerokotorowej: na Litwę 22, na Ukrainę - 14, na Białoruś - 10, do Kazachstanu - 1, oraz 125 normalnotorowych SZT: do Włoch - 85, do Czech - 31 i do Niemiec - 9. Ponadto 2 pojazdy inspekcyjne sprzedano do Rosji. Natomiast Newag sprzedał do Włoch 4 wąskotorowe SZT.

Produkcja elektrycznych zespołów trakcyjnych (EZT) w Polsce była prowadzona od lat pięćdziesiątych XX wieku. W wyniku załamania rynku w latach dziewięćdziesiątych XX wieku powstało tylko kilkadziesiąt składów EZT, a następnie przez kilka lat nie prowadzono produkcji nowych. Jedynym ówczesnym producentem tego typu taboru w Polsce był PaFaWag we Wrocławiu, gdzie do 1994 roku powstawały pojazdy serii EN57, a w latach 1992-1998 wyprodukowano 21 składów ED72 (Transport Szynowy, 2017). Od 2004 roku produkcją EZT w Polsce zajmowały się Pesa oraz Newag, obydwa przedsiębiorstwa wyprodukowały do 2016 roku łącznie 259 pojazdów, co stanowiło 32,8\% nowych pojazdów wyprodukowanych w latach 2002-2016. Udział Pesy w całej produkcji polskich producentów nowych EZT w tym okresie wyniósł 60,9\%, a Newagu $-40,1 \%$. Natomiast od 2016 roku liderem produkcji EZT w Polsce stał się Newag. Do 2010 roku wielkość produkcji była stosunkowo niewielka. Krajowi przewoźnicy 
Ryc. 2. Kraje przeznaczenia wyprodukowanych przez polskich producentów SZT w latach 2002-2016

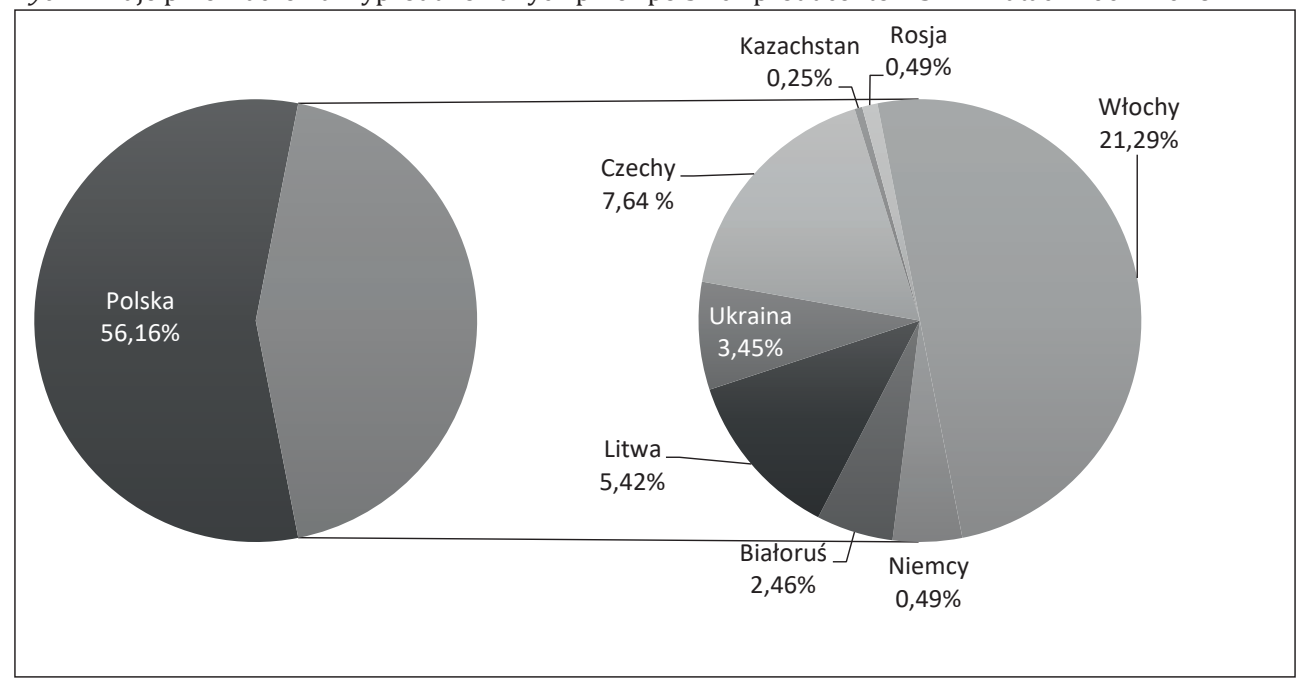

Źródło: opracowanie własne na podstawie Pesa wyprodukuje... (2006); Grobelny (2010); Graff, Šalčiunas (2012); Pesa zdobywa... (2012); Czesi kupujq... (2013); Pesa ma rekord... (2013); Produkcja eksportowa... (2016); Pesa liderem... (2016)

inwestowali przede wszystkim w modernizację starszych sprawdzonych pojazdów głównie EN57, ze względu na niższe koszty w porównaniu z zakupem całkowicie nowych. Dopiero od 2011 roku wielkość produkcji wzrosła i w 2013 roku produkcja EZT przewyższyła produkcję SZT. Po 2011 roku z zakładów wychodziło rocznie od 28 do 41 pojazdów (ryc. 3). Pesa produkowała stworzone przez siebie EZT serii Elf, Acatus Plus i Dart, zaś Newag składy z rodziny Impuls (tab. 1). W przypadku EZT zdecydowana większość produkcji była przeznaczona na rynek krajowy, wyeksportowano jedynie pięć pojazdów Newagu do Włoch (Newag S.A., 2017).

EZT były ponadto częściowo produkowane przez zagraniczne koncerny Bombardier i Stadler w zakładach na terenie Polski. W zakładzie Stadler Polska od 2007 roku powstawały składy z rodziny Flirt. W latach 2007-2016 powstało tam 312 EZT, z których 54 trafiły na rynek krajowy, a pozostałe za granicę, do: Niemiec, Estonii, Włoch, Węgier, Holandii i na Białoruś (Stadler Polska, 2017). Natomiast w zakładach Bombardiera we Wrocławiu powstawały jedynie nadwozia pojazdów przeznaczone głównie na rynek zagraniczny. Z Wrocławia pochodziły nadwozia do składów TALENT, a od 2016 roku także do pociągów dużych prędkości ICx - dla kolei niemieckich DB (Superszybkie..., 2016).

Produkcja nowych lokomotyw w Polsce, podobnie jak w przypadku EZT, pod koniec lat dziewięćdziesiątych XX wieku została przerwana. Do 1992 roku Fablok Chrzanów produkował lokomotywy spalinowe serii SM42. Natomiast elektrowozy wytwarzane były w zakładach HCP - seria EU07 w latach 1983-1992 oraz PaFaWag - EP09 w latach 1989-1997. Ponadto w latach 1990-1991 w zakładzie HCP powstały cztery prototypowe egzemplarze lokomotyw elektrycznych serii EM10 (Irteński, 2013). Wymienione wyżej pojazdy oprócz EM10 są nadal użytkowane i poddawane modernizacjom. Na przełomie XX i XXI wieku produkcja polskich lokomotyw została wstrzymana, prowadzono jedynie modernizacje starszych pojazdów, głównie produkcji polskiej i radzieckiej. 
Ryc. 3. Produkcja taboru kolejowego przez polskich producentów w latach 2002-2016

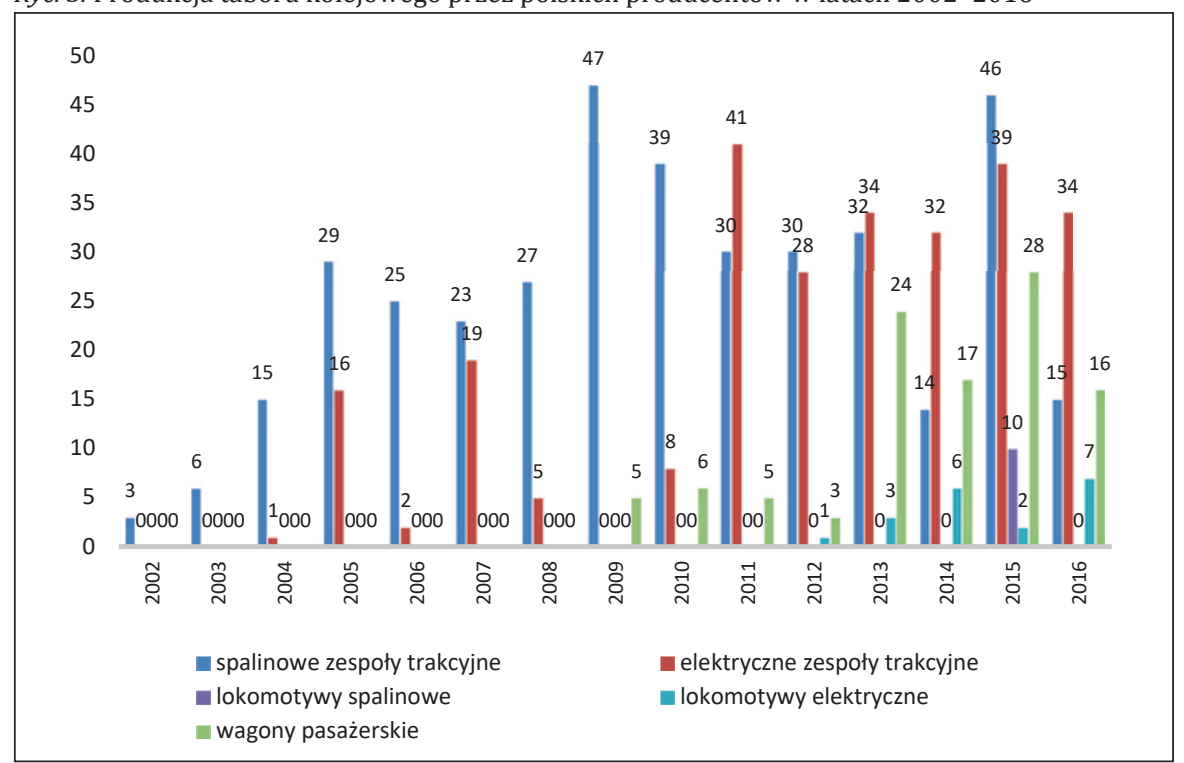

Źródło: opracowanie własne na podstawie informacji publikowanych przez producentów taboru; urzędy marszałkowskie województw; Etmanowicz (2014); Nowe wagony... (2015); PKP Intercity prezentuje... (2015); Baza wagonów kolejowych (2017)

Polskie przedsiębiorstwa rozpoczęły produkcję nowych lokomotyw dopiero pod koniec pierwszej dekady XXI wieku. ZNLE Gliwice, a potem Newag produkowały elektrowozy E6ACT Dragon od 2009 roku i E4MSU Griffin od 2013 roku. Natomiast Pesa stworzyła rodzinę lokomotyw Gama: spalinowóz 111Db produkowany od 2014 roku, elektrowóz wielosystemowy 111MS oraz lokomotywę elektryczno-spalinową Marathon 111Ed powstałą w 2015 roku. W latach 2012-2016 Newag wyprodukował 14, a Pesa 15 lokomotyw różnych typów (ryc. 3) (Dostawy..., 2017; PKP Intercity, 2017).

W zakładach Bombardier we Wrocławiu powstawały pudła do lokomotyw z rodziny Traxx, zaś ich finalny montaż odbywał się poza Polską, m.in. w zakładzie w Kassel w Niemczech. Były to elektrowozy jedno- lub wielosystemowe, a także elektryczno-spalinowe przeznaczone głównie na rynek zagraniczny. Łącznie wyprodukowano tam ponad 2 tys. pudeł lokomotyw (Sprawdzony..., 2008).

Produkcja wagonów pasażerskich również uległa ograniczeniu, m.in. ze względu na spadek przewozów w Polsce oraz zastosowanie w większym stopniu SZT w ruchu regionalnym, a potem także EZT w ruchu dalekobieżnym. Ponadto modernizowano stare wagony, co również powodowało mniejszy popyt na nowe. Do połowy lat dziewięćdziesiątych XX wieku głównymi producentami wagonów pasażerskich w Polsce były PaFaWag i Fabryka Wagonów i Lokomotyw - późniejszy HCP FPS. W pierwszej dekadzie XXI wieku nie powstawały nowe wagony, jedynie w 2009 roku Pesa wyprodukowała pięć wagonów doczepnych do SZT (BIP Urzędu..., 2017). W latach 2010-2015 w zakładach HCP FPS powstało 79 nowych wagonów (PKP Intercity prezentuje..., 2015; Baza wagonów..., 2017). Ponadto Pesa w 2015 roku wyprodukowała 20 wagonów piętrowych, w tym dwa z kabinami sterowniczymi (Koleje Mazowieckie, 2017) (ryc. 3). Nowe wagony z polskich zakładów przeznaczone były głównie na rynek krajowy. 
Analiza produkcji wagonów towarowych i pojazdów specjalnych jest utrudniona ze względu na brak oficjalnych i pełnych danych w tym zakresie. Wagony towarowe były produkowane przez pięć spółek, w tym dwie należące do koncernu Greenbrier Europe. Natomiast pojazdy specjalne, służące m.in. do utrzymania i naprawy infrastruktury kolejowej, wytwarzały dwa zakłady, w tym jeden podmiot zagraniczny (por. tab. 1).

Produkcja w zakładach zagranicznych koncernów na terenie Polski była skierowana przede wszystkim na rynki zagraniczne. W zakładzie Stadler w Siedlcach powstało łącznie 54 EZT dla polskich przewoźników, w tym 14 w 2008 roku, 17 w 2014 roku i 23 w 2015 roku. Natomiast Bombardier wyprodukował 24 pudła do lokomotyw, które potem trafiły do Polski (Graff, 2007; LOTOS Kolej rozpoczyna..., 2011; Koleje Mazowieckie, 2017; PKP Intercity, 2017).

\section{ModernizaCJA TABoru W POLSCE}

Działalność związana z modernizacją taboru miała w Polsce bardzo duże znaczenie i zajmowali się tym wszyscy polscy producenci taboru oraz zakłady naprawcze. Modernizacja była przeprowadzana m.in. w ramach napraw rewizyjnych czwartego i piątego poziomu utrzymania. Szacuje się, że od początku XXI wieku poddano modernizacji w Polsce ponad 1 tys. pojazdów i zespołów trakcyjnych - czyli o 1/3 więcej niż wyprodukowano nowych. Najwięcej pojazdów stanowiły EZT serii EN57 oraz lokomotywy EU07 i SM42. Ogółem zmodernizowano prawie 350 EZT, prawie 700 lokomotyw i ok. 120 wagonów pasażerskich (tab. 3).

Modernizacja taboru kolejowego jest o wiele tańsza niż zakup nowego taboru. Przebudowywano i unowocześniano lokomotywy, EZT i wagony polskiej produkcji, a ponadto lokomotywy radzieckie, np. M62 - chętnie wykorzystywane przez przewoźników prywatnych i PKP LHS do prowadzenia ciężkich pociągów towarowych. Zakres niektórych modernizacji był tak duży, że niezmieniona pozostawała jedynie rama i ostoja wózków. W przypadku radzieckiej lokomotywy spalinowej M62 została ona przerobiona w zakładzie przewoźnika Rail Polska na elektrowóz 207E - prototyp został zaprezentowany podczas targów TRAK02017, a w planach jest przebudowa w ten sposób kolejnych 30 pojazdów (Madrjas, 2017). W ramach modernizacji wagonów pasażerskich część wagonów przedziałowych przebudowano na bezprzedziałowe.

Tab. 3. Modernizacja taboru kolejowego w Polsce w latach 2001-2016

\begin{tabular}{|c|c|c|c|c|}
\hline \multicolumn{3}{|c|}{ Pojazdy kolejowe } & \multirow{2}{*}{$\begin{array}{l}\text { Liczba } \\
\text { pojazdów }\end{array}$} & \multirow{2}{*}{$\begin{array}{c}\text { Zakłady } \\
\text { przeprowadzające } \\
\text { modernizacje }\end{array}$} \\
\hline Rodzaj & $\begin{array}{c}\text { Seria przed } \\
\text { modernizacją }\end{array}$ & Seria lub typ po modernizacji & & \\
\hline \multicolumn{3}{|c|}{ Ogółem } & 1086 & - \\
\hline \multirow{5}{*}{ EZT } & \multicolumn{2}{|l|}{ Razem } & 342 & - \\
\hline & EN57 & $\begin{array}{l}\text { EN57SP0T, EN57KM, EN57AKM, } \\
\text { EN57AKŁ, EN57AL, EN57AKD, } \\
\text { EN57AKS, EN57AKW, EN57AP, } \\
\text { EN57EPS, EN57ALc i d. }\end{array}$ & 327 & $\begin{array}{l}\text { Konsorcjum Pesa } \\
\text { i ZNTK Mińsk } \\
\text { Mazowiecki, Newag }\end{array}$ \\
\hline & EN71 & $\begin{array}{l}\text { EN71AC, EN71SP0T, EN71KM, } \\
\text { EN71 AKŚ }\end{array}$ & 9 & $\begin{array}{l}\text { ZNTK Mińsk } \\
\text { Mazowiecki, Newag }\end{array}$ \\
\hline & ED72 & ED72A & 6 & $\begin{array}{l}\text { ZNTK Mińsk } \\
\text { Mazowiecki }\end{array}$ \\
\hline & M62 & $207 \mathrm{E}$ & 1 & Rail Polska \\
\hline
\end{tabular}




\begin{tabular}{|c|c|c|c|c|}
\hline \multirow{4}{*}{$\begin{array}{l}\text { Lokomotywy } \\
\text { elektryczne }\end{array}$} & \multicolumn{2}{|l|}{ Razem } & \multirow{2}{*}{$\begin{array}{r}267 \\
68\end{array}$} & \multirow{2}{*}{\begin{tabular}{|l|}
- \\
ZNLE Gliwice, \\
PKP Cargo \\
\end{tabular}} \\
\hline & ET22 & ET22 & & \\
\hline & EU07 & EU07A & 3 & ZNTK Oleśnica \\
\hline & EU07 & EP07, EU07P & 196 & $\begin{array}{l}\text { ZNTK Oleśnica, Pesa, } \\
\text { Newag, HCP FPS }\end{array}$ \\
\hline \multirow{8}{*}{$\begin{array}{l}\text { Lokomotywy } \\
\text { spalinowe }\end{array}$} & \multicolumn{2}{|l|}{ Razem } & 397 & - \\
\hline & $\begin{array}{l}\text { SM42 } \\
\text { (Ls800E) }\end{array}$ & $\begin{array}{l}\text { SU42, SM42, } \\
\text { 6Dc, 6Dd,6De, 6Dg, 6Dh, 6Di,6Dk, } \\
\text { 6Dl, 6Dm, 18D, }\end{array}$ & 187 & $\begin{array}{l}\text { Newag, Pesa, Orion } \\
\text { Kolej, Cz Loko, Tabor } \\
\text { Dębnica, ZNTK Poznań }\end{array}$ \\
\hline & SU45 (301D) & ST45 (303D) & 19 & Pesa \\
\hline & SU46 (301D) & ST46 (302Da) & 1 & Pesa \\
\hline & \begin{tabular}{|l|} 
ST44 \\
\end{tabular} & ST44 & 54 & Pesa \\
\hline & \multirow{2}{*}{ ST44 (M62) } & M62M, M62Y, M62BF, M62Ko, & 93 & \multirow{2}{*}{ Pesa } \\
\hline & & ST40s & 15 & \\
\hline & SM48 & ST48 & 42 & Newag \\
\hline Wagony & $\begin{array}{l}\text { 110A, 111A, } \\
112 \mathrm{~A}, 113 \mathrm{~A}\end{array}$ & $\begin{array}{l}\text { 155A, 507A, 508A, 308A, 306Ab, } \\
\text { 140A, 161A, 162A, 163A, 170A, } \\
171 \mathrm{~A}\end{array}$ & $120^{*}$ & $\begin{array}{l}\text { Pesa, Newag, } \\
\text { H. Cegielski, } \\
\text { TS Opole }\end{array}$ \\
\hline
\end{tabular}

Uwaga: podano nr serii według nomenklatury PKP, a w przypadku jego braku lub eksploatacji przez przewoźników spoza grupy PKP - nr serii stanowiący typ fabryczny

* wielkość szacunkowa

Źródło: opracowanie własne na podstawie informacji publikowanych przez urzędy marszałkowskie, PKP Intercity (2017), Newag (2017), Rynek Kolejowy (2017)

\section{PROBLEMY ROZWOJU POLSKICH PRODUCENTÓW TABORU KOLEJOWEGO}

Po wejściu Polski do UE i pojawieniu się funduszy unijnych, z których można było pozyskać dofinansowanie, znacznie wzrósł popyt na nowy tabor kolejowy na rynku krajowym. Pojawienie się dużej liczby zamówień od krajowych przewoźników, pospiesznie wydających środki z funduszy UE z kończącej się perspektywy finansowej 2007-2013, oraz niewystarczające moce produkcyjne polskich zakładów spowodowały problemy z terminową realizacją dostaw zamówionych pojazdów. W konsekwencji producent musiał płacić kary umowne. Taka sytuacja dotyczyła przede wszystkim Pesy - największego polskiego producenta taboru. Kolejnym problemem była wysoka awaryjność niektórych pojazdów - tzw. błędy wieku dziecięcego. Były to konstrukcje nowe, często prototypowe, a polskie przedsiębiorstwa dopiero uczyły się wytwarzania nowoczesnego taboru, zgodnego z europejskimi standardami. Nie było czasu na dokładne testowanie prototypów w warunkach normalnej eksploatacji, ponieważ pojazdy musiały stosunkowo szybko trafić do seryjnej produkcji. Największe tego typu problemy wystąpiły w przypadku lokomotywy spalinowej SU160 z rodziny Gama, produkowanej przez Pesę. Wskaźnik dostępności tego pojazdu w latach 2015-2016 wynosił od 54,5\% do 72,8\%. Nieco mniej awaryjny był EZT tego samego producenta ED161 Dart - współczynnik dostępności od 76,2\% do 95,3\%. Należy jednak zaznaczyć, że współczynnik ten uwzględnia także sytuacje, w których dany pojazd był niedostępny z przyczyn losowych, niezależnych od producenta (Junduła, 2017, 18 kwietnia). W konsekwencji Pesa może stracić szansę na zamówienie kolejnych dartów (Polskie Pendolino..., 2017). Ze 
względu na bardziej skomplikowaną budowę SZT w porównaniu z EZT- zwłaszcza silników, duże problemy z awaryjnością występowały także w nowych SZT.

Istotnym problemem był brak kompatybilności pojazdów kolejowych, zarówno nowych, jak i modernizowanych, uniemożliwiający zestawienie składu pociągów z SZT lub EZT różnych serii. Wynikało to w dużym stopniu z wprowadzania ciągłych zmian i innych systemów sterowania. W przypadku pojazdów zmodernizowanych było to spowodowane różnymi wykonawcami, jednak problemy tego typu zdarzały się również w nowych pojazdach tego samego producenta. Może to prowadzić do zwiększenia kosztów obsługi pociągów ponoszonych przez przewoźnika, z powodu konieczności zwiększenia obsady pociągu czy uniemożliwienia wykorzystania w pełni możliwości danego pojazdu.

Kolejnym problemem były trudności w uzyskaniu homologacji polskich pojazdów za granicą - głównie w Niemczech, m.in. z powodu braku dopuszczenia pojazdu w Niemczech Pesa była zmuszona do dostarczenia województwu lubuskiemu w ramach rekompensaty dwóch nowych SZT typu Link (Madrjas, 2017, 23 października).

Część potencjału polskiego przemysłu kolejowego została zmarnowana. W badanym okresie, pomimo ożywienia na krajowym rynku kolejowym, upadły m.in. ZNLS Piła, ZNTK Poznań i Fablok Chrzanów. Firmy te miały długoletnie tradycje w produkcji taboru kolejowego. Ponadto porzucono niektóre innowacyjne projekty z lat dziewięćdziesiątych XX weku, m.in.: zaniechano produkcji rozwojowej serii elektrycznych lokomotyw manewrowych EM10 (Wach, 2014) oraz w niewielkim stopniu wykorzystywano system samoczynnej zmiany rozstawu kół SUW 2000 (Bocheński, 2017).

Polscy producenci byli nastawieni na realizację zamówień dla krajowych przewoźników, realizowanych w ramach projektów dofinansowanych z funduszy UE i EFTA. Powodowało to znaczne wahania w wielkości produkcji. Ponadto w większości przypadków najważniejszym kryterium w przetargach była najniższa cena, co odbijało się na jakości taboru. Należy jednak zaznaczyć, że polskie firmy pomału, ale w coraz większym stopniu wchodzą także na rynki zagraniczne - wyeksportowano ponad $40 \%$ produkcji SZT. Powstające pojazdy są coraz nowocześniejsze i zaczynają dorównywać ofercie zagranicznych koncernów. Problemem jest jednak ograniczony krajowy rynek podzespołów i konieczność importu części. W następnych latach, dzięki planom wymiany taboru polskich przewoźników kolejowych, polscy producenci będą mieli zapewnione zamówienia. Ponadto Pesa i Newag prowadziły projekty rozwojowe finansowane ze środków NCBiR

Dodatkowe dochody dla producentów taboru dawały usługi związane z serwisowaniem i przeglądami sprzedanych pojazdów. Usługi te w okresie od kilku do kilkunastu lat ujęte były w większości umów na zakup taboru. W przyszłości mogą one stanowić ważny i stały dochód dla producentów.

\section{PODSUMOWANIE I WNIOSKI}

Przemysł taboru kolejowego w Polsce, po kryzysie na przełomie XX i XXI wieku wynikającym z sytuacji w PKP oraz procesów transformacji gospodarczej kraju, zaczął się ponownie rozwijać. Duży wpływ na to miało wejście Polski do UE oraz finansowanie projektów taborowych ze środków pomocowych. Dodatkowo otwarcie rynku kolejowego i pojawienie się kilkudziesięciu przewoźników umożliwiło dywersyfikację zamówień. Prężnie rozwijało się zwłaszcza dwóch największych producentów - Pesa i Newag, 
którzy coraz większą część swojej produkcji eksportowali. Stawiali oni na nowe rozwiązania technologiczne i nowoczesny design. Nie obyło się jednak bez problemów technicznych z produkowanym taborem oraz opóźnień w realizacji kontraktów. W konsekwencji PESA w 2017 roku miała problemy finansowe. Swoje zakłady w Polsce posiadały także zagraniczne koncerny. Bombardier i Greenbier przejęły istniejące fabryki w wyniku prywatyzacji, zaś Stadler wybudował zakład od podstaw.

W miarę zdobywania doświadczenia poprawia się jakość produkowanych pojazdów - zwiększa się współczynnik dostępności. Ważne jest wsparcie polskich producentów i umożliwienie im dopracowania własnych konstrukcji pojazdów. Polscy przewoźnicy powinni być zobligowani do zakupu przede wszystkim polskiego taboru, podobnie jak to się dzieje w Niemczech. Tabor produkowany przez zagraniczne koncerny jest lepiej dopracowany właśnie dlatego, że przez lata jego zakup był preferowany na rynkach krajowych. W dalszym rozwoju branży szczególnie istotny będzie rozwój produkcji na eksport. Po 2022 roku programy pomocowe UE będą znacznie okrojone i prawdopodobnie spadnie popyt na nowy tabor na rynku krajowym. Ponadto konieczna będzie produkcja taboru zgodnego z TSI, głównie zespołów trakcyjnych i lokomotyw hybrydowych (spalinowo-elektrycznych). Ważny będzie również rozwój produkcji podzespołów i usług serwisowych.

\section{Literatura}

\section{References}

Balicka, M. (2013, 23 maja). Sąd ogłosił upadłość Fabloku. Syndyk zlikwiduje zakład? Gazeta Krakowska. Pozyskano z http://www.gazetakrakowska.pl/artykul/901261, sad-oglosil-upadlosc-fabloku-syndyk-zlikwiduje-zaklad,id,t.html

Balicka, M. (2015, 11 grudnia). Chrzanów. Fablok powstał jak Feniks z popiołów. Rusza produkcja. Gazeta Krakowska. Pozyskano z http://www.gazetakrakowska.pl/artykul/9180970, chrzanow-fablok-powstal-jak-feniks-z-popiolow-rusza-produkcja, id,ththtml

Baza wagonów kolejowych (2017, grudzień). Pozyskano z http://bazawagonow.pl/wagonyfps. html

BIP Urzędu Marszałkowskiego Województwa Kujawsko-Pomorskiego (2017, grudzień). Pozyskano z http://bip.kujawsko-pomorskie.pl

Bocheński, T. (2016). Powiązania kolei z przemysłem w drugiej dekadzie XXI wieku. Prace Komisji Geografii Przemysłu Polskiego Towarzystwa Geograficznego, 30(4), 50-64.

Bocheński, T. (2017). Funkcjonowanie rejonów przeładunkowych na styku sieci kolejowych o rozstawie torów 1435 i 1520 mm w Europie. Prace Komisji Geografii Przemysłu Polskiego Towarzystwa Geograficznego, 31(3), 80-94. DOI: 10.24917/20801653.313.6

Cieśla, R. (2016, 10 lipca). Poznań: Koniec ZNTK, czyli atrakcyjne grunty pod młotek. Głos Wielkopolski. Pozyskano z http://www.gloswielkopolski.pl/magazyn/a/poznan- koniec-zntk-czyli-atrakcyjne-grunty-pod- mlotek,10381761/

Czesi kupują kolejne polskie pociagi z PESY Bydgoszcz (2013, 5 kwietnia). Newsweek. Pozyskano z http://www.newsweek.pl/biznes/wiadomosci- biznesowe/czesi-kupuja-kolejne-polskie-pociagi-z-pesy-bydgoszcz, 103167,1,1.html

Dostawy lokomotywy elektrycznych zrealizowane przez polskich producentów (2017, 1 sierpnia). InfoRail. Pozyskano z http://inforail.pl/dostawy-lokomotywy- elektrycznych-zrealizowane-przez-polskich-producentow_more_97323.html

EKK Wagon (2017, 30 grudnia). Pozyskano z http://www.ekk-wagon.pl/Ofirmie/Historia/tabid/371/ language/pl-PL/Default.aspx

Etmanowicz, A. (2014). Wagony osobowe standardu Z1 „nowej generacji” klasy pierwszej typu 156A (166A) oraz drugiej typu 156A (167A). Świat Kolei, 11, 28-33. 
Fabryka Wagonów Gniewczyna S.A. (2017, 30 grudnia). Pozyskano z http://www.gniewczyna. $\mathrm{pl} / \mathrm{pl} / \mathrm{o}$-firmie/historia/

Fiszer, K. (2016, 9 kwietnia). Koniec wielkich nadziei taborowych z lat 90. Rynek Kolejowy. Pozyskanozhttp://www.rynek-kolejowy.pl/wiadomosci/koniec-wielkich-nadziei-taboro wych-z-lat-90- 76099.html

Graff, M. (2007). Lokomotywy Bombardiera TRAXX F140 MS dla PKP Cargo. Technika Transportu Szynowego, 12, 18.

Graff, M., Šalčiunas, R. (2012). Spalinowe wagony silnikowe produkcji Pesy na kolejach Litwy i Białorusi. Świat Kolei, 11, 15-19.

Grobelny, M. (2010). Polscy eksporterzy w branży kolejowej. Rynek Kolejowy, 2, 53.

H. Cegielski - Fabryka Pojazdów Szynowych Sp. z o.o. (2017, 30 grudnia). Pozyskano z http:// fpspoznan.pl/o-firmie/historia/

Interlok Sp. z o.o. (2017, 30 grudnia). Pozyskano z http://www.interlok.info/indexpl1.htm

Irteński, T. (2013). Lokomotywy. Polskie konstrukcje. Warszawa: Wydawnictwo SBM.

Janduła, M. (2017, 18 kwietnia). Flirty najbardziej niezawodne. Tuż za nimi Pendolino. Rynek Kolejowy. Pozyskano z http://www.rynek-kolejowy.pl/wiadomosci/niezawodne-flirty-tuz-za--pendolino-81296.html

Koleje Mazowieckie (2017, 30 grudnia). Pozyskano z http://www.mazowieckie.com.pl/

Lerch, R. (2012) Modernizacja taboru szynowego - cele, zamierzenia, efekty. Przegląd Komunikacyjny, 7-8, 10-13.

Lotos Kolej (2017, 30 grudnia). Pozyskano z http://www.lotoskolej.pl/2198/o_nas/o_firmie

LOTOS Kolej rozpoczyna eksploatacje pierwszej lokomotywy TRAXX F140 DE (2011, 1 lipca). Pozyskano z http://www.lotos.pl/322/p,174,n,3406/grupa_kapitalowa/centrum_prasowe /aktualnosci/lotos_kolej_rozpoczyna_eksploatacje_pierwszej_lokomotywy_traxx_f140_de

Madrjas, J. (2016, 21 kwietnia). Przewozy Regionalne same zrobiły naprawę P4. Rynek Kolejowy. Pozyskano z http://www.rynek-kolejowy.pl/wiadomosci/ przewozy-regionalne-same-zrobily-naprawe-p4-76298.html

Madrjas, M. (2016, 3 czerwca). Pierwszy polski pociąg z dopuszczeniem dla Niemiec. Wielki sukces Linka Pesy. Rynek Kolejowy. Pozyskano z http://www.rynek-kolejowy.pl/wiadomosci/pierwszy-polski-pociag-z- dopuszczeniem-dla-niemiec-wielki-sukces-linka-pesy-76845.html

Madrjas, J. (2017, 26 września). Elektryczny Gagarin odkryciem Trako. Rynek Kolejowy. Pozyskano z http://www.rynek-kolejowy.pl/wiadomosci/ elektryczny-gagarin-odkryciem-trako-tego-nikt-sie-nie-spodziewal-83662.html

Madrjas, J. (2017, 23 października). Pesa dostarczy lubuskiemu dwa nowe Linki zamiast kar. Rynek Kolejowy. Pozyskano z http://www.rynek-kolejowy.pl/mobile/ Pesa-dostarczylubuskiemu-dwa-nowe-linki-zamiast-kar-84053.html

Mavex-Rekord Kft. (2017, 30 grudnia). Pozyskano z http://mavex-rekord.pl/1-O-nas/1-Charakterystyka- firmy.html

Narada w sprawie Fabryki Wagonów w Gniewczynie (2017, 27 marca). Twoje Miasto Przeworsk. Pozyskano z http://mojprzeworsk.pl/2017/03/narada-sprawie-fabryki-wagonow-gniewczynie/

Newag Gliwice (2017, 30 grudnia). Pozyskano z http://web.archive.org/web/20130927151953/ http://www.newaggliwice.pl/pl/firma/historia.html

Newag S.A. (2017, grudzień). Pozyskano z http://www.newag.pl/o-firmie/historia/

Nowe wagony od Cegielskiego wyjadą na początku przyszłego roku (2015, 30 grudnia). InfoRail. Pozyskano z http://inforail.pl/nowe-wagony- od-cegielskiego-wyjada-na-poczatku-przyszlego -roku-film-_more_80539.html

Pesa Bydgoszcz S.A. (2017, 30 grudnia). Pozyskano z http://www.Pesa.pl

Pesa dokupiła 25 proc. akcji ZNTK Mińsk Mazowiecki (2017, 30 grudnia). Railway Busines Forum archiwum. Pozyskano z http://web.archive.org/web/20170824145658/http: //www.rbf. net.pl/wiecej,PESA-dokupila- 25-proc-akcji-ZNTK-Minsk-Maz,505

Pesa liderem dostaw pociągów na Litwę (2016, 25 listopada). InfoRail. Pozyskano z http://inforail.pl/Pesa-liderem-dostaw-p ociagow-na-litwe_more_89337.html

Pesa ma rekord prędkości pociągu spalinowego - 201 km/h (2013, 16 października). Rynek Kolejowy. Pozyskano z http://web.archiv e.org/web/20131021000402/http://www.rynek-kolejowy.pl/48654/Pesa_ma_rekord_predkosc i_pociagu_spalinowego_201_km_h.htm 
Pesa wyprodukuje pociągi dla Włochów (2006, 13 czerwca). Rynek Kolejowy. Pozyskano z http:// www.rynek-kolejowy.pl/wiadomosci/Pes a-wyprodukuje-pociagi-dla-wlochow-69244. html

Pesa zdobywa Kazachstan (2012, 1 sierpnia). Kurier Kolejowy. Pozyskano z https://kurierkolejowy.eu/aktualnosci/9270/Pesa-zdoby wa-kazachstan.html

Piech, R. (2007, 6 listopada). ZNTK Poznań/ Sigma na Trako. InfoTram. Pozyskano z http://www. infotram.pl/zntk-poznan-sig ma-na-trako_more_66749.html

Pierwsza Fabryka Lokomotyw w Polsce Fablok S.A. (2017, 30 grudnia). Pozyskano z http:// www.fablok.com.pl/

PKP Intercity (2017, grudzień). Pozyskano z https://www.intercity.pl/

PKP Intercity prezentuje nowe wagony na trasę Warszawa - Szczecin (2015, 30 grudnia). Rynek Kolejowy. Pozyskano z http://www.r ynek-kolejowy.pl/wiadomosci/pkp-intercity-prezentuje-nowe-wagony-na-trase-w arszawa--szczecin-zdjecia-73772.html

Polskie Pendolino rozczarowuje. PKP Intercity nie chce pociagów od Pesy (2017, 22 maja). Pozyskano z http://forsal.pl/artykuly/1044622,Pe sa-dart-polskie-pendolino-rozczarowuje-pkp-inter city-nie-chce-pociag ow-od-pesy.html

Produkcja eksportowa PESY w 2016 roku (2016, 22 grudnia). InfoRail. Pozyskano z http://inforail.pl/produkcja-ek sportowa-pesy-w-2016-roku_more_90 349.html

Rail Polska Sp. z o.o. (2017, 30 grudnia). Pozyskano z http://ww w.railpolska.pl/ztk.html

Railway Busines Forum (2017, 30 grudnia). Pozyskano z http://www.rbf.net.pl/czlonkowiewiecej,Wagony-Swidnica-SA,38

Rynek Kolejowy (2017, 30 grudnia). Pozyskano z https://www.rynek- kolejowy.pl/

Sobolewski, P. (2001). Pafawag dziś i jutro. Świat Kolei, 9, 16-18.

Sprawdzony partner (2008, 30 grudnia). Folder informacyjny o Bombardier Transportation w Polsce. Pozyskano z http://pl.bombardier.com/Bombardier_Transportation_Poland.pdf

Stadler Polska Sp. z oo. (2017, 30 grudnia). Pozyskano z http://www.stadlerrail.com/en/about-us/locations/stadler-polska-sp-z-oo/

Superszybkie bombardiery z Polski. Rusza produkcja pociagów dla Deutsche Bahn (2016, 25 października). Pozyskano z http://forsal.pl/artykuly/987706, superszybkie-bombardiery-z-polski- rusza -produkcja-pociagow- dla -deutsche-bahn.html

Tabor Dębica Sp. z o.o. (2017, 30 grudnia). Pozyskano z http://www.tabor-debica.pl

Transport Szynowy (2017, 30 grudnia). Pozyskano z http://www.transportszynowy.pl/eztdane. php\#en57

Turowski, A. (2012). EU07 typu 303Ec - nowe spojrzenie na modernizacje. Przegląd Komunikacyjny, 7-8, 52-57.

Wach, K. (2014, 23 czerwca). EM10 do kasacji. InfoRail. Pozyskano z http://inforail.pl/em10-do-kasacji_more_34611.html

Wagon Opole Sp. z o.o. (2017, 30 grudnia). Pozyskano z http://wagonopole.com.pl/

WSO Ostróda Sp. z.o.o. (2017, 30 grudnia). Pozyskano z http://www.wsostroda.eu/pl/

ZASTAL S.A. (2017, 30 grudnia). Pozyskano z http://www.zastal.pl/

Zastal robi ważny krok, by znów produkować wagony (2014, 27 lipca). Gazeta Wyborcza Zielona Góra. Pozyskano z http://zielonagora.wyborcza.pl/zielonagora/1,35182,16388471,Zastal_ robi_wazny_krok_by_znow_produkowac_wagony.html

ZNTK Mińsk Mazowiecki S.A. (2017, 30 grudnia). Zakłady Napraw Taboru Kolejowego. Pozyskano z http://zntkmm.pl/

ZNTK Oława Sp. z o.o. (2017, 30 grudnia). Zakłady Napraw Taboru Kolejowego. Pozyskano z http://www.zntk.olawa.pl/

ZNTK Radom Sp. z o.o. (2017, 30 grudnia). Zakłady Napraw Taboru Kolejowego. Pozyskano z http://www.zntkradom.pl/pl/

ZNTKiM Sp. z o.o. (2017, 30 grudnia). Zakłady Napraw Taboru Kolejowego. Pozyskano z http:// zntkim.pl/ofirmie.html

ZPS Sp. z.o.o. (2017, 30 grudnia). Zakład Pojazdów Szynowych. Pozyskano z http://www.mtrzps. com.pl/pl/o-firmie/historia

Sebastian Wojtkiewicz, mgr inż., doktorant, Uniwersytet Szczeciński, Wydział Nauk o Ziemi, Instytut Geografii Społeczno-Ekonomicznej i Gospodarki Przestrzennej, Zakład Badań Miast i Regionów. Specjalizuje się 
w geografii transportu. Prowadzi badania m.in. z zakresu funkcjonowania kolei oraz komunikacji miejskiej. W polu jego zainteresowań znajdują się również przemiany przestrzenne w miastach.

Sebastian Wojtkiewicz, M.Sc., Ph.D. student at the University of Szczecin, Faculty of Geosciences, Institute of Socio-Economic Geography and Spatial Management, Urban and Regional Study Unit. He specialises in transport geography. He conducts research on the functioning of railways and public transport. His academic interests also include spatial changes in cities.

\title{
Adres/address:
}

\author{
Uniwersytet Szczeciński \\ Wydział Nauk o Ziemi \\ Instytut Geografii Społeczno-Ekonomicznej i Gospodarki Przestrzennej \\ Zakład Badań Miast i Regionów \\ ul. Mickiewicza 18, 70-383 Szczecin, Polska \\ e-mail: sebastianwojtkiewicz@gmail.com
}

Tadeusz Bocheński, dr, adiunkt, Uniwersytet Szczeciński, Wydział Nauk o Ziemi, Instytut Geografii Społeczno-Ekonomicznej i Gospodarki Przestrzennej, Zakład Badań Miast i Regionów. Specjalizuje się w geografii transportu. Prowadzi badania m.in. z zakresu funkcjonowania kolei i transportu intermodalnego oraz ich powiązań z przemysłem. W polu jego zainteresowań znajduje się również funkcjonowanie portów morskich i delimitacja regionów funkcjonalnych.

Tadeusz Bocheński, Ph.D., assistant professor at the University of Szczecin, Faculty of Geosciences, Institute of Socio-Economic Geography and Spatial Management, Urban and Regional Study Unit. He specialises in transport geography. He conducts research on the functioning of railways and intermodal transport and their connections with industry. His academic interests also include the delimitation of functional regions.

\section{Adres/address:}

\author{
Uniwersytet Szczeciński \\ Wydział Nauk o Ziemi \\ Instytut Geografii Społeczno-Ekonomicznej i Gospodarki Przestrzennej \\ Zakład Badań Miast i Regionów \\ ul. Mickiewicza 18, 70-383 Szczecin, Polska \\ e-mail: tadeusz.bochenski@usz.edu.pl
}

